Islam directs." He then laments the adoption by leaders of Muslim nations in the post-colonial era of "the Western secular political systems" to handle their affairs, reflecting "their ignorance of Islamic values, merits, and especially vision..." The reality he evokes is indeed a sore wound that has multiplied the sufferings of Muslim countries in recent decades. However, the perception that this is a uniquely modern situation, and 'Islam' was more fully implemented and practised in the past, needs to be re-examined. The simplistic glorification of an idealised past has clouded much of contemporary Muslim thinking and various Islamic political projects for an 'Islamic State', so it is vital that responsible researchers not perpetuate such cherished soothing myths. A self-critical and honest appraisal of the strengths and weaknesses which our past imposes is necessary for Muslims to move forward and construct their own authentic mode of modernity. Diplomatic practices form one important component of that enterprise.

\title{
Saim Kayadibi (ed.), Ottoman Connections to the Malay World: Islam,
} Law and Society (Kuala Lumpur: The Other Press, 2011) 267 pp. ISBN 978983954-177-9. MYR 39.00

\section{Eric Winkel International Institute of Advanced Islamic Studies (IAIS) Malaysia}

This book is a carefully researched work that may serve as an important resource for the study of Ottoman and other Muslim connections and networks to the Malay Archipelago. The spread of Islam in the region through trade is well documented here. The authors of the seven articles contained in this volume have used original sources - many of them very little known or used in contemporary scholarship. The authors are strongly supported by their sources to contribute to a re-writing of the history of this region.

The chapter "The Religious-Intellectual Network: The Arrival of Islam in the Archipelago" by Nurulwahidah binti Fauzi, Ali Mohammad, and Saim Kayadibi corrects common misperceptions about Islam, the Arabian lands, and Southeast Asia and shows them to be intimately linked. In the early period, it was natural for the Arabs to extend their trading relations to the Malay Archipelago. The early ArabPersian records trace Arab connections with Malaya and Indonesia back to the midninth century. Islam spread through trade and education (e.g., establishing pesantrens) in this region. This chapter also examines the important network of Hadrami Arabs and Johor. By the late nineteenth century, the Arab community in Glam Village (Singapore) was described by Dutch scholar L. W. C. Van den Berg in 1886 as "the most flourishing, though not the largest, Arab colony in the Indian Archipelago." The 
Ottoman Empire also had strong ties to the region, and in the nineteenth century, supported anti-imperialist struggles throughout the archipelago.

The second chapter by Mehmet Özay introduces the seventeenth-century Turkish scholar Baba Davud. He may have been a soldier "deployed by the Ottomans to help the Aceh sultanate defend itself against the Portuguese." He established an educational center in Aceh and completed his teacher's work, considered to be "the first Malay-language translation and commentary of the Qur'an."

The third chapter by Ahmet Akgündüz is a fascinating look at a zāwiyah in Banda Aceh, the Dayah Tanoh Abee. We see here that Sufism and the spiritual dimension of Islam were very much part of the orthodox Sunni outlook and that this zäwiyah was not only a place of education and scholarship but of active efforts to lead the anti-Dutch struggle.

The editor's contribution, "The Evolution of the Muslim Judicial System," provides a very helpful summary of legal developments in Islam. Of particular interest is the cosmopolitan legal system of the Ottomans, which could deal with a great variety of peoples, ethnicities, cultures, and religions. This is an important source for developing the fiqh of minorities, especially now that many Muslims are part of minority communities.

In "Judicial Pluralism in the Malaysian Legal System," the editor applies some of these ideas to the particular situation in Malaysia.

In this book, the Ottoman connections over the centuries are shown to be quite extensive. For someone familiar with Malaysian personalities, it is fascinating to learn of these connections: Ruqayyah Hanım coming from Istanbul to marry Dato' Jaafar (with children including Dato' Onn and a grandchild, Tun Hussein), and after being widowed, marrying Abdullah al-Attas, and having scholarly sons. The current prime-minister of Malaysia, Mohd Najib Abdul Razak, has Turkish blood from the same family tree.

The authors of this book have used original works to develop a picture of these and more connections to the Malay world which serves as a foil to narrow, group politics and which shows us the universality of the vision of Islam found in the key figures of the region over the centuries. 